\title{
MANAGEMENT ANALYSIS OF BUSINESS ENVIRONMENT IN UKRAINE IN THE CONTEXT OF FOREIGN ECONOMIC PROCESSES
}

The state of business environment in a country plays a major role in the effective functioning of the economy. External economic aspects are of particular importance for Ukraine, given the integration and the need in investment. The aim of the article is to identifythe assessment methods of the state ofthe business environment in Ukraine, determineopportunities and constraints of respective rating andactualindicators, particularly foreign investment. The approaches to estimating the state of the business environment in Ukraine are analyzed. Indicative features of a number of rating indicators developed by various international organizations are determined. Foreign investment indicators are suggested to use as the resultant actual indicators of the state of the business environment in Ukraine. The paper concludes that one of the priorities of the State's foreign economic policy should be to create appropriate conditions for foreign investment in the country's economy. In general, the global investment movement is not a sustainable process, its dynamic is dependent on many factors. It is important to proceed from the assumption that highquality managerial decisions, as a rule, require high-quality analytical work-primarily about the business environment of the companies (existing and potential). Of particular importance is the quality level of such analysis for the adoption of effective decisions in the field of foreign economic activity. Therefore, the issue of improving the study of the state of the business environment in one or another economy becomes relevant in both the theoretical and practical sense. Rating (index) indicators of business environment assessment in the country occupy a very important place in analytical management work. They are, in particular, guidelines for foreign investors in assessing the investment attractiveness of the environment and making managerial decisions.

Key words: enterprise, businessenvironment, indicators of the state of the businessenvironment, management, foreign investment.

JEL Classification: M1, E66, F21.

Yurii PETRUNIA,

University of Customs and Finance, Ukraine

Vira PETRUNIA,

University of Customs and Finance, Ukraine

\section{Introduction}

The businessenvironment of enterprises is a certain system of factors and entities, whose activities influence the conditions, capabilities and results of entrepreneurial activity of enterprises. A prerequisite for effective managerial decisions is a qualitative analysis of the business environment, which ultimately sought to find business chances and identify business risks for enterprises.

The State is one of the key institutions that influences conditions, dynamics and prospects of changes in the environment of enterprises. Such an effect is feltboth by residents and by non-residents. The foreign economic policy of the State is accompanied by a tangible impact of state institutions 
on the foreign economic activity of enterprises, on foreign economic aspects of the business environment.

One of the priorities of the State's foreign economic policy should be to create appropriate conditions for foreign investment in the country's economy. In general, the global investment movement is not a sustainable process, its dynamic is dependent on many factors.

Thus, according to the UNCTAD World Investment Report 2018, foreign direct investment (FDI) flows declined by $23 \%$ in 2017 to 1.43 trillion USD [1]. The decrease in flows means, in particular, the intensification of competition for attracting foreign investment. In general, each country is constantly looking for chances in the world system of the movement of capital. Ukraine sorely needs efficient searches in this area. The state of the business environment in Ukraine, including its foreign economic aspects and the prospects for its change are key factors that determine the interest of residents and non-residents in investing in the country's economy.

\section{Analysis of recent research and publications (theoretical basis)}

Regular studies of individual components of the business environment in relation to particular countries are provided by professionals. The latter work within the framework of certain projects devoted to the systematic study of the relevant aspects of the business environment in one or another economy. In particular, we can highlight Doing Business [2], World Economic Forum [3], IMD World Competitiveness Center [4], European Business Association [5] Corruption perceptions index [6]. The recent publications of Ukrainian authors are devoted to the problems of the business environment. Among them one can mention in particular the research by M. Miller (development of classification approaches to the analysis of the business environment [7]), L. Kobilyanska, H. Shvets (assessment of the business environment of small and medium enterprises [8, 9]), I. Beloy and N. Nasikan (features of the business environment in Ukraine [10]), Yu. Vysnyak (corruption component of the environment [11]), G. Buryak (protection of private property rights [12]), S. Terrible (the role of the State in the formation of the environment [13]).

At the same time, it is important to proceed from the assumption that high-quality managerial decisions, as a rule, require high-quality analytical work - primarily about the business environment of the companies (existing and potential). Of particular importance is the quality level of such analysis for the adoption of effective decisions in the field of foreign economic activity. Managers need a benchmarking system, a set of indicators that they could use in their analytical work to assess the current and future status of a business environment. Therefore, the issue of improving the study of the state of the business environment in one or another economy becomes relevant in both the theoretical and practical sense.

The purpose of the article is to determine the approaches to assessing the state of the business environment in Ukraine, to identify opportunities and limitations of relevant rating and factual indicators, in particular foreign investment.

\section{Results}

In the theory and practice of management one of the basic concepts is the term "environment". Then it is divided into "internal environment" and "external environment". It can be said that management of the internal environment is carried out by the owners and managers of the organization. Nevertheless, the external environment serves a certain given system component. Considering the notion of "business environment", it should be noted that it is close to the concept of "external environment" of the organization. The difference between them, in our opinion, is that the "external environment" is a broader term than the "business environment". 
So, firstly, not every organization is a business organization. In such a case, the organization obviously has an appropriate environment for its activities, but it can not be interpreted as a business environment. Secondly, it is important to note the presence of a large number of state and utility companies that act in an environment that is devoid of sufficient amount of attributes for the business environment itself. One example of the foregoing is the lack of competition in some of these enterprises, which does not allow us to determine the environment of their activities as the business environment itself. At the same time, we can assert that most of the enterprises are operating within the business environment.

In accordance with the above-mentioned, there is interest in conducting an assessment of the state of the business environment in a given country through a system of indicators. That is, to find such a set of indicators of the state and dynamics of the environment, which would give managers acceptable precision characteristics of the conditions of entrepreneurship in a particular country or within the framework of some other territorial-administrative or contractual formation. The use of such indicators is an important component of analytical management work.

One of the most well-known in this respect is the World Bank's Doing Business (DB) ranking of ease of doing business in different countries. The country's overall indicator is formed as an average for a number of parameters (indicators) - for example, the possibility of obtaining loans, the conditions for registration of enterprises, the tax burden, the degree of protection of investors, licensing procedures for businesses, etc. Figure 1 shows the position of Ukraine regarding the main indicators of the rating DB-2019 [2].

Entityregistration- реєстрація підприємства

Buildingpermits - отримання дозволу на будівництво

Connectiontoenergysystems - підключення до систем енергозабезпечення

Property registration - реєстрація власності

Obtaining loans - отримання кредиту

The protection of minority investors - захист міноритарних інвесторів

Taxation - оподаткування

International trade - міжнародна торгівля

Enforcement of contracts - забезпечення виконання контрактів

Solution to the insolvency problem - вирішення проблеми неплатоспроможності

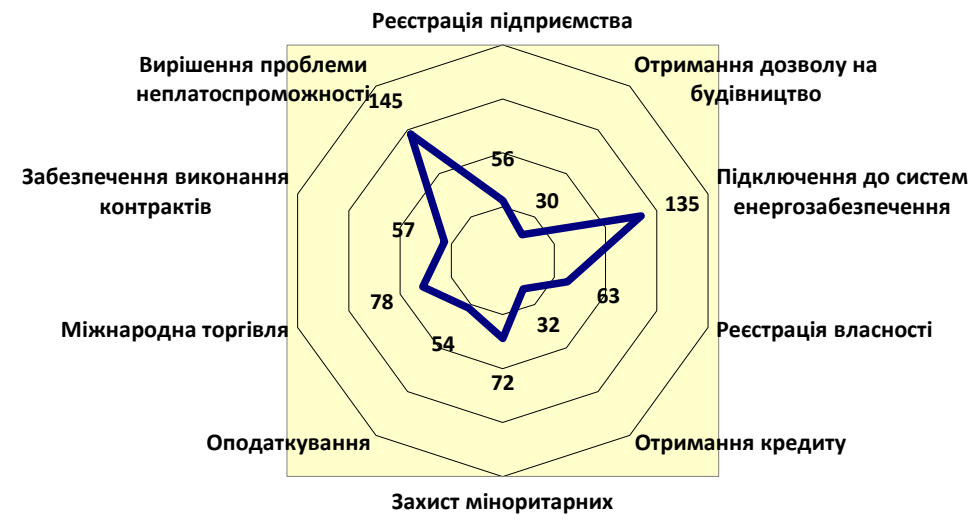

Fig. 1. Positions of Ukraine on core components of Doing Business rating 2019

Source: compiled by authors on the basis of [2]. 
It should be noted that Ukraine has shown positive dynamics in the DB rating over the last years. Thus, Ukraine has risen to 80th position from the 83d in the DB-2017 rating; the $83 \mathrm{~d}$ position was reached in the DB-2016 rating. For comparison, we state that in 2011, 2013, 2014 Ukraine was at 152, 137, 112 places, respectively. In the DB-2018 rating and DB-2019 rating, Ukraine has again shown some progress - moving to 76 and 71 positions respectively (out of 190 countries). For comparison, we state that positions of Belarus and Moldova in the DB-2019are 37 and 47, respectively. If we take separate components of the rating of Ukraine (Figure 1), then we note that according to DB-2019, the main positive changes occurred on the following indicators: protection of minority investors (from 81 to 72), international trade (from 119 to 78 ), and enforcement of contracts (from 82 to 57 ).

It should be pointed out that the DB General Index (rating) is indeed a certain integral indicator. But at the same time, from a strictly scientific point of view, it cannot be accepted as a sufficiently comprehensive indicator to characterize the business environments of individual economies. In our opinion, it can be considered as a certain integral indicator, which characterizes the "rules of the business game", which are set by a certain state. The quality of these "rules" is an extremely important characteristic of the business environment of the country, but they are only part of the image of the state of the business environment. For example, in this Index, we do not see resource-factor characteristics, assessments of the state of infrastructure, macroeconomic conditions, stability of the financial and banking system, traditions of business conducting, etc. This is not to say that these parameters are secondary in terms of assessing the environment of enterprises.

Thus, it can be noted that the DB Index is aimed at assessing the quality of the rules and procedures for regulating business activities in a particular country. In terms of the role of the state in formation of the business environment, we can really agree that this Index is probably one of the best indicators, which also characterizes the state of foreign economic regulation in one or another country.

A larger scale project is the Global Competitiveness Index (World Economic Forum) calculations. It should be noted that in the 2017-2018 rating, Ukraine ranked 81 st out of 137 countries for this indicator [3]. In our opinion, this Index may qualify for one of the most systematic assessments of the status of business environments in individual countries. First, a fairly large number of measurement indicators are used (113, which are grouped into 12 groups). Secondly, both expert assessments and statistical data are used. The latter circumstance reduces the influence of the subjective factor. Thirdly, accents are made not only on "rules of the game", on state regulation, but also on resource factors, infrastructure, etc. Eventually, the idea of GCI is to assess the country's ability to provide acceptable economic growth in the medium term. The ability to grow is a positive signal (indicator) for a business, because it means that there are prerequisites for a certain increase in demand, to expand the capacity of certain markets. Probably such calculations, such assessments are useful for analytical management work at the company level, especially those who carry out large-scale international activities.

In the GCI 2017-2018 rating, Ukraine scored 4.1 points (81st place). It should be noted that countries occupying rating places from 76 to 86 inclusive have the same score. In preliminary calculations, Ukraine's place was as follows: 2015-2016 - 79, 2016-2017 - 85 (4.0 points). This is to say, in general, the positive rating dynamics of Ukraine is insignificant. At the same time, however, it is important to take into account the fact that the presence in the Index of resources, infrastructures and a number of other objectively "inertial" indicators-components affects the ability of countries and public institutions to relatively quickly change the situation. It should be noted that in the GCI 2017-2018 the best indicator in Ukraine is "Higher Education" (35 rating 
place, 5.1 points), the worst are "Macroeconomic Conditions" (121 rating place, 3.5 points) and "Financial Markets Development" (120 rating place, 3.1 points). Among the most significant problems of business conducting in Ukraine are identified, in particular, inflation (16.3 - weight out of 100) and corruption (13.9).

Another index-rating option for assessing the competitiveness of a country as a whole is the IMD World Competitiveness Ranking. In 2018, the best components for Ukraine were "Skills" (46th out of 140 countries), "Market Scope" (47th place), "Infrastructure' (57th place), "Innovative Capacity" (58th place). The worst were "Macroeconomic stability" (131st place), "Financial system" (117th place), "Institutions" (110th place). As we can see, the estimated components of this rating are to some extent correlated with the components of the GCI 2017-2018 [4].

Useful analytical material includes calculations of the Index of Economic Freedom. To determine this Index, 10 indicators are used, each of which is evaluated by a 100-point system. Under the Index-2017 Ukraine scored 48.1 points. 1.3 points were added to the previous period. Ukraine falls into a group of countries with a "non-free economy" with such amount of points. In the last 10 years, the lowest indicator in Ukraine was in $2011-45.80$ points, and the highest in $2006-54.40$ points. According to the Index-2018, Ukraine scored 51.9 points. 3.8 points were added to the index of the previous year, but it is only 150 position from 180 countries [14].

The European Business Association (EBA) calculates the Investment Attractiveness Index, which is based on an expert survey of top managers of member companies of the Association. When determining the index, respondent assessments of the business climate in a particular country are taken into account. Index indicators for Ukraine are 2.57 points (according to a fivepoint scale) at the end of 2015, 2.85 at the end of 2016. At the end of 2017, the index rose to 3.03, it came out of the so-called "negative zone", and went to the "neutral zone" (above 3.0). For the first half of 2018, the index was 3.10 [5]. It should be noted that for the last ten years this indicator for Ukraine was the highest at the end of $2010-3.4$ points. The main problems of the business environment in Ukraine in 2018 were a high level of corruption (46.1\% of respondents), lack of trust in the judicial system (40.6\%) and lack of land reform (35.9\%).

In our opinion, the Investment Attractiveness Index, on the one hand, is useful for conducting a business climate analysis, but on the other hand, it cannot be a sufficiently convincing instrument (indicator) of the state of the business environment in the country. In particular, its essential disadvantage in this regard is that it is based on subjective assessments. We can predict that expert judgment also influences such factors as the success of one's own business in the analyzed period. Such factors as branch (market) dynamics, dynamics of exchange rates, availability of certain resources in the future, etc., can influence the investment mood. It is rather obvious that we can define this Index as an index of business mood.

Often enough, researchers are paying attention to the problem of taxation, as a factor in the state of the business environment. As the analysis shows, the issue of taxation is really significant for any investor, it is important for taking appropriate managerial investment decisions on the directions and spheres of investment. But it is not decisive. The key issue with regard to the business environment of Ukraine, if put out of account the factors of the potential of a particular market, its strategic prospects, it is the level of protection of investors' rights, achievement of equality before the law of all business entities, and ensuring conditions for fair competition. Corruption prevents fair competition. Corruption has different manifestations and dimensions. In particular, it manifests itself in the "administrative-power" redistribution of corporate rights, "selectivity" in the conduct of public procurement procedures, "selectivity" in economic justice, and so on. Ukraine 
still needs to do a lot in fighting corrupt practices in the economic sphere. Thus, according to the level of perception of corruption, Ukraine ranked 130th out of 167 in the ranking of the International Organization Transparency International [6]. Such situation is, of course, a factor limiting the investment interest of non-residents in relation to the Ukrainian economy.

In our opinion, all the indicators analyzed above (indices) are estimated indicators of business conditions. An assessment of the environment through the evaluation of its conditions is an important analytical work. But no less important is the assessment of the environment through the results of its functioning. If we rely on the indicators of the actual-resultant nature, that is, those that characterize the actual functioning of the environment, the results of activities, including the state as a regulator of economic activity, then, in our opinion, we must pay special attention to indicators of foreign direct investment. Perhaps these indicators are the most accurate reflection of the level of business interest in a particular economy in all its aspects. That is, this indicator can be considered as a kind of focal, generalizing the perception of business conditions of entrepreneurship in a particular country.

In 2015, the volume of foreign direct investment (share capital) in the Ukrainian economy amounted to 3.764 billion USD. In 2016, this indicator grew up to $17.1 \%$, reached 4.4 billion USD. It should be noted that investments in financial and insurance activities made up a dominant share, and their total volume in 2016 amounted to 2.825 billion USD [15]. At the beginning of 2017, the total accumulated volume of direct foreign investments in the Ukrainian economy amounted to 37.325 billion USD. In total, in 2017, 1.9 billion USD of direct investmentwas invested (Figure 2). For half of 2018, the volume of attraction of foreign direct investment in the economy of Ukraine amounted to 1.3 billion USD. It is still difficult to assess the business environment in Ukraine as attractiveaccording to such results.

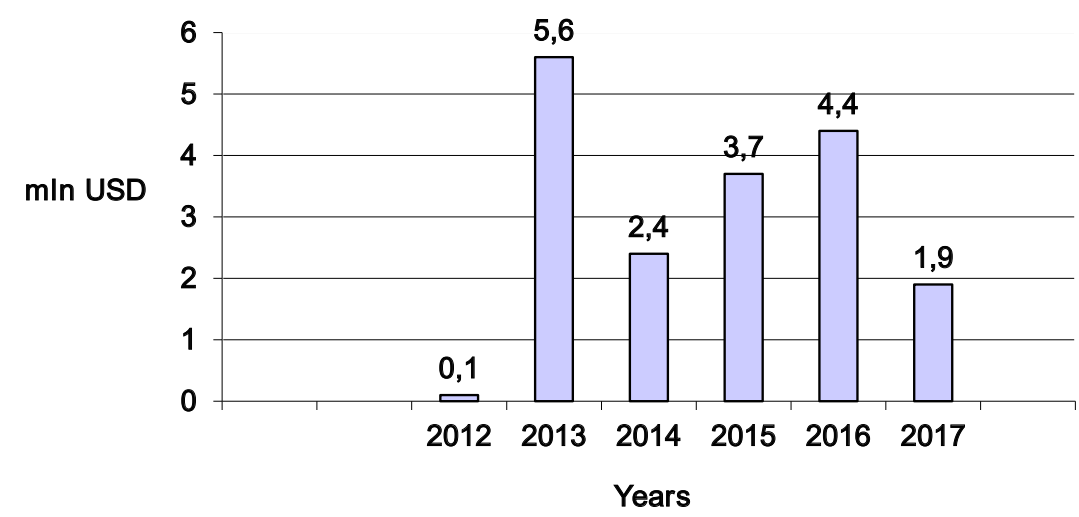

Fig. 2. Annual income of foreigndirect investments (share capital) in the economy of Ukraine for 2012-2017

Source: compiled by authors on the basis of [15].

In our opinion, the indicators of attracting foreign direct investment into the country are one of the most important indicators in assessing the state of the business environment in the country. They give us the opportunity to evaluate the business environment not so much under its terms (legislative and some others), as on the results, on the actual interest and actions on the placement of business in this environment. For the sake of completeness, in our opinion, it is 
important to note that foreign investment is also a factor of adjustment, making changes in the business environment of the country.

We will try to compare the dynamics of individual rating indicators and indicators of foreigndirect investment in the economy of Ukraine. The Table 1 shows the comparison of the DB rating for Ukraine and the annual volumes of foreign direct investment in the country. Data analysis does not show us the correlation between indicators; the rating indicators are increasing, but there is no stable growth of foreign investment indicators. Why is this happening? Does it because the growth of the ratings is rather slow and not very significant? Maybe yes. But, it is highly likely that this is also evidenced by the fact that rating indicators, in particular, DB, at best is only a part of a possible overall assessment of the state of the business environment in the country. That is, it can be assumed that the assessment of certain business conditions in the country is not sufficient for a comprehensive overall assessment of the state of the business environment in the country.

Table 1

DB rating indicators and amount of direct investment (share capital) receipts from non-residents to Ukraine

\begin{tabular}{|c|c|c|}
\hline Year & $\begin{array}{c}\text { Place in DB rating } \\
\text { (at the beginning of the year) }\end{array}$ & $\begin{array}{c}\text { Capital receipts } \\
\text { (billion USD at the end of the year) }\end{array}$ \\
\hline 2012 & 152 & 0,1 \\
\hline 2013 & 137 & 5,6 \\
\hline 2014 & 112 & 2,4 \\
\hline 2015 & 96 & 3,7 \\
\hline 2016 & 83 & 4,4 \\
\hline 2017 & 80 & 1,9 \\
\hline 2018 & 76 & 1,3 (for 6 months) \\
\hline
\end{tabular}

Source: compiled by authors on the basis of [2, 15].

An important aspect for analyzing foreign investment in Ukraine is the study of information on countries from which foreign direct capital flows into the country's economy. The fact is thata significant part in the structure of foreign direct investment in Ukraine is traditionally madeby investments of companies registered in offshore areas. Statistics do not provide an opportunity to accurately determine to what extent offshore investment is truly "foreign investment". Researchers do not have sufficient opportunity to determine the real origin of a significant part of foreign investment. This is out of question, complicates the use of the indicator of direct foreign investment to assess the perception and dynamics of the state of the business environment in the country.

It is possible to predict that the dynamics of the statistical indicators of foreign direct investment into the economy of Ukraine is largely determined by the corresponding management decisions of those entrepreneurs who are used to actively put forth offshore zones in their business practice. It is obvious that political, macroeconomic, as well as other factors, correct the business behavior and processes of offshore capital movements.

Foreign investors make a decision on investing on the basis of subjective assessments of the appropriateness of such investment. It is useful to have a simultaneous management assessment of both investment potential (investment benefits) and investment risks. The latter are the risks associated with entering the new marketing environment into a new system of regulatory coor- 
dinates. Balance of comparisons of advantages and risks determines one or another managerial decision.

There is no doubt that the most attractive form for the importing countries of capital, including for Ukraine, is the receipts of foreigndirect investment. It is traditionally believed that these investments have a certain positive impact on the economy, contributing to increased production and GDP, the introduction of new forms and tools for management, the creation of new jobs, the recovery of competition, etc. But at the same time it is necessary to pay attention to other important points. It is known that foreign direct investment is aimed at staying in the country for a long time. These investments are not only a certain movement of capital with all its positive consequences in the sense of an additional resource, they are simultaneously the introduction of certain business traditions, business culture, business standards in the management community and management practices, in the system of relations both private and the public sector of the economy [16].

\section{Conclusions}

Rating (index) indicators of business environment assessment in the country occupy a very important place in analytical management work. They are, in particular, guidelines for foreign investors in assessing the investment attractiveness of the environment and making managerial decisions. For foreign investors, it is very important that the host country grants guarantees concerning the protection and security of the investor's investment, ensures the preservation of foreign ownership, protects the rights and interests of a foreign investor in its territory, etc. Rating indicators are the factor of certain influence on processes of formation and development of the business environment in the country, on the activities of state institutions as organizations responsible for the quality of certain components of the public administration system in the country. At the same time, the attitude to rating indicators should take into account the fact that they: firstly, focus on certain aspects of the business environment; and secondly, the business environment is assessed through the characteristics of its conditions, and not by the resulting indicators of its functioning. Concerning the definition of indicators of the actual and resultant nature, perhaps, one of the key indicators is the attraction of foreign direct investment in the economy.

\section{References:}

1. UNCTAD. World Investment Report 2018: [Electronic resource]. - Available at: http://unctad.org.

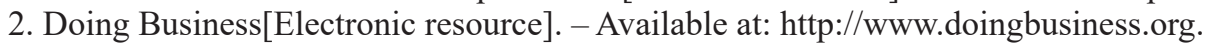

3. World Economic Forum [Electronic resource]. - Availableat: http://www.weforum.org/reports.

4. IMD World Competitiveness Center [Electronic resource]. - Available at: http://www.imd.org.

5. European Business Association [Electronic resource]. - Available at: http://www.eba.com.ua

6. Corruption perceptions index[Electronic resource]. - Available at: http://cpi.transparency.org.

7. Мельник М. І. Класифікація бізнес середовища: системний підхід / М.І. Мельник // Регіональна економіка. - 2008. - № 2. - С. 251-260. (Meljnyk M. I. Klasyfikacija biznes seredovyshha: systemnyj pidkhid / M.I. Meljnyk // Reghionaljna ekonomika. - 2008. -\# 2. - S. 251-260.)

8. Візняк Ю. Я. Діагностика бізнес-середовища підприємства і роль неурядових організацій щодо запобігання та протидії корупції у сфері оподаткування / Ю.Я Візняк, P.М. Скриньковський, Т.Б. Процюк // Бізнесінформ. - 2016. - № 1. - С. 235-240. (Viznjak Ju. Ja. Diaghnostykabiznes-seredovyshhapidpryjemstva i roljneurjadovykhorghanizacijshhodozapobighannjataprotydijikorupciji u sferiopodatkuvannja / Ju.JaViznjak, R.M. Skrynjkovsjkyj, T.B. Procjuk // Biznesinform. - 2016. - \#1. - S. 235-240.)

9. Кобилянська Л. М. Сучасне бізнес-середовище для підприємств малого та середнього бізнесу в Україні / Л. М. Кобилянська // Фінансово-економічне та обліково-аналітичне 
забезпечення підприємницької діяльності: збірник тез доповідей учасників Міжнародної науково-практичної конференції, Черкаси, 20-21 квітня 2016 р. - Черкаси: Східноєвропейський університет економіки і менеджменту, 2016. - C. 243-245. (Kobyljansjka L. M. Suchasnebiznes-seredovyshhedljapidpryjemstvmaloghotaserednjoghobiznesu v Ukrajini / L. M. Kobyljansjka // Finansovo-ekonomichnetaoblikovo-analitychnezabezpechennjapidpryjemnycjkojidijaljnosti: zbirnyktezdopovidejuchasnykivMizhnarodnojinaukovo-praktychnojikonferenciji, Cherkasy, 20-21 kvitnja 2016 r. - Cherkasy: Skhidnojevropejsjkyjuniversytetekonomiky i menedzhmentu, 2016. - S.243-245.)

10. Біла І.С., Насікан Н.І. Бізнес-середовище в Україні // Глобальні та національні проблеми економіки. - 2017. - № 17. - C. 127-131. (Bila I.S., Nasikan N.I. Biznes-seredovyshhe v Ukrajini // Ghlobaljnitanacionaljniproblemyekonomiky. - 2017. - \#17. - S. 127-131.)

11. Швець Г.О. Сучасне середовище малого та середнього підприємництва в Україні // Вісник Приазовського державного технічного університету. Серія: Економічні науки. - 2017. Вип. 24. - С. 31.-39. (ShvecjGh.O. Suchasneseredovyshhemaloghotaserednjoghopidpryjemnyctva v Ukrajini // VisnykPryazovsjkoghoderzhavnoghotekhnichnoghouniversytetu. Serija: Ekonomichninauky. - 2017. - Vyp. 24. - S. 31.-39.)

12. Буряк Г. Інститути розвитку відносин власності у класифікації бізнес-середовища / I. Буряк // Актуальні проблеми міжнародних відносин. - 2012. - Випуск 105. - Ч. II. - С. $26-28$ (BurjakGh. Instytutyrozvytkuvidnosynvlasnosti u klasyfikacijibiznes-seredovyshha / I. Burjak // Aktualjniproblemymizhnarodnykhvidnosyn. - 2012. - Vypusk 105. - Ch. II. - S. 26-28.)

13. Страшний С.Бізнес-середовище як об'єкт державного регулювання / С. Страшний // Актуальні проблеми державного управління. - 2010. - Вип. 2. - С. 61-64 [Електронний peсурс]. - Режим доступу : http://nbuv.gov.ua/UJRN/ apdyo_2010_2_20. (Strashnyj S. Biznes-seredovyshhejakob'jektderzhavnoghoreghuljuvannja / S. Strashnyj // Aktualjniproblemyderzhavnoghoupravlinnja. - 2010. - Vyp. 2. - S. 61-64 [Elektronnyjresurs]. - Rezhymdostupu : http://nbuv.gov.ua/UJRN/ apdyo_2010_2_20.)

14. Україна у глобальнй рейтингах [Електронний ресурс]. - Режим доступу: http://www.pravda.com.ua. (Ukraina u globalnyhreityngah. Availableat:http://www.pravda.com.ua).

15. Державна служба статистики України. Статистична інформація. Зовнішньо економічна діяльність [Електронний ресурс]. - Режим доступу: http://www.ukrstat.gov.ua. (DerzhavnasluzhbastatystykyUkrajiny. Statystychnainformacija. Zovnishnjoekonomichnadijaljnistj. Availableat: http://www.ukrstat.gov.ua).

16. Оптимізація систем управління в умовах економічної глобалізації : монографія / за ред. д.е.н. Ю. С. Петруні. - Дніпро: Університет митної справи та фінансів, 2018. - С. 91 (Орtymizacijasystemupravlinnjavumovakhekonomichnojighlobalizaciji :monoghrafija / zared. d.e.n. Ju. Je. Petruni. - Dnipro: Universytetmytnojispravytafinansiv, 2018. - S. 91).

\section{УПРАВЛІНСЬКИЙ АНАЛІЗ СТАНУ БІЗНЕС-СЕРЕДОВИЩА В УКРАЇНІ В КОНТЕКСТІ ЗОВНІШНЬОЕКОНОМІЧНИХ ПРОЦЕСІВ}

\section{Юрій ПЕТРУНЯ,}

Університет митної справи та фінансів, Україна

Віра ПЕТРУНЯ,

Університет митної справи та фінансів, Україна

Стан бізнес-середовища в країні відіграє суттєву роль в ефективності функиіонування економіки. Для України зовнішньоекономічні аспекти середовища мають особливе значення, враховуючи інтегрованість та потребу в інвестиціях. Метою статті є визначення підходів щзодо проведення оцінки стану украйнського бізнес-середовища, виявлення можливостей та обмежень відповідних рейтингових та фактичних показників, зокрема іноземного інвестування. Проаналізовано підходи до оцінювання стану бізнес-середовища в Україні. Визначено індикаторні можливості ряду рейтингових показників, які розробляються різними міжнародними 
організаціями. Запропоновано використовувати в якості результуючих фактичних показників стану бізнес-середовища в Украӥні показники іноземного інвестування. Зазначено, щзо одним із пріоритетів зовнішньоекономічної політики держави має полягати у створенні відповідних умов при надходженні іноземних інвестицій в економіку крайни. В иілому, світовий рух інвестицій ие не сталий процес, динаміка його є залежною від багатьох факторів. Якісні управлінські рімення, як правило, потребують якісної аналітичної роботи - насамперед щуодо бізнессередовища діяльності компаній (існуючого та потенційного). Особливого значення рівень якості такого аналізу набуває для прийняття ефективних рішень в сфері зовнішньоекономічної діяльності. Тому питання вдосконалення дослідження стану бізнес-середовища в тій чи іншій економіки набуває актуальності як в теоретичному, так $i$ практичному сенсі. Рейтингові (індексні) показники оцінки бізнес-середовища в країні займають своє, досить важливе місие в аналітичній управлінській роботі. Вони є, зокрема, орієнтирами для іноземних інвесторів при оцінці інвестищійної привабливості відповідного середовища та прийнятті управлінських рішень.

Ключові слова: підприємство, бізнес-середовище, показники стану бізнес-середовища, управління, іноземне інвестування. 